\title{
ISO 9004 - A STIMULATING QUALITY MANAGEMENT STANDARD FOR THE CREATIVE LEADERS OF CONTEMPORARY ORGANIZATIONS
}

\author{
ISO 9004 - STIMULATIVNA NORMA UPRAVLJANJA KVALITETOM \\ ZA KREATIVNE LIDERE SUVREMENIH ORGANIZACIJA
}

\author{
Juhani Anttila, M. Sc. \\ Academician, (IAQ - International Academy for Quality) \\ Rypsikuja 4, FI-00660 Helsinki, Finland/Finska \\ E-mail: juhani.anttila@gmail.com \\ Kari Jussila, M. Sc. \\ University of Helsinki, Faculty of Pharmacy, \\ Viikinkaari 5e, FI-00014 Helsingin yliopisto, Finland/Finska \\ E-mail: kari.jussila@helsinki.fi
}

UDK/UDC: 006.35(100)ISO:005.6

JEL klasifikacija/JEL classification: L15

DOI: $10.30657 /$ hdmk.2020.06

Pregledni članak/Review

Jezik/Language: Engleski/English

\begin{abstract}
An organization can reap significant benefits from generic international management standards if one understands the nature of those standards and applies them creatively and integrated with business management. In this case, the leaders of the organization play a key role. This article considers the subject in all kinds of organizations and focuses specifically on the ISO 9004 quality management standard, one of many international management standards. ISO 9004 standard is the most challenging standard in the ISO 9000 quality management (QM) standards series. Often, however, organizations applying the ISO 9000 standards have not clearly recognized the differences and relationship of the ISO 9004 and ISO 9001 standards and hence have not been able to exploit the potential of the standard in their QM implementations. The ISO 9004 standard emphasizes that the organization's identity and its differentiating competitive advantages are the basis for the organization's sustained success. Each organization has its own and always existing ISO 9000 QM realization that can be continually improved according to the organization's business development strategies and practices. In this respect, the ISO 9004 is very flexible and challenging. In addition to the ISO 9000 standards, organizations also use other well-known managerial reference models, including, for instance, performance excellence models and many other management system standards of the specific disciplines. All these may be seen as subdomains within the ISO 9004 implementation. In addition to the opportunities, the article also discusses some of the practical difficulties and pitfalls associated with the ISO 9004 standard, and their possible solutions. Since the 1980s, the first author of this article has gathered experience in the international preparation process of the ISO 9004 standard-editions and both authors in the practical promotion and application of the standard in different kinds of organizations.
\end{abstract}

Key words: quality, quality management, ISO 9004, sustained success, organizations' quality. 


\section{INTRODUCTION}

Business benefits of the generic international standards can only be realized if the organization understands the nature of the standards and is able to implement them creatively within the business management. In this case, the leaders of the organization play a key role. This article considers the subject in all kinds of organizations and focuses specifically on the ISO 9004 quality management (QM) standard (ISO 2018a), which is one of many international management standards (ISO/IEC 2019).

Specialized expertise areas, which are required for organizational management, include, in addition to QM, among others asset management, dependability management, environmental protection, information security management, occupational health, safety management, risk management, social responsibility, etc., which also are dealt with in the corresponding international management system standards. These specific managerial areas, 'XXX', are abstract issues and hence cannot be managed directly. The 'XXX' management in an organization is defined as the management of an organization with regard to the 'XXX' (Ibid.). According to this principle, also QM is defined as the management of an organization with regard to quality.

Standardization related to management systems, including the ISO 9000 standardization, is a part of the general international standardization. Therefore, the general concepts, principles, and aims, as well as the pros and cons of standardization, apply to QM standardization, too. The most basic concepts, standardization and standard, are defined as follows (ISO/IEC 2004):

- Standardization: An activity giving solutions for repetitive application, to problems essentially in the spheres of science, technology and economics, aimed at the achievement of the optimum degree of order in a given context. Generally, the activity consists of the processes of formulating, issuing and implementing standards.

- Standard: A technical specification or other document available to the public, drawn up with the cooperation and consensus or general approval of all interests affected by it, based on the consolidated results of science, technology and experience, aimed at the promotion of optimum community benefits and approved by a standardization body.

In line with these general purposes, international standardization does seek to benefit all types of organizations and the whole society. ${ }^{1}$ Those benefits include:

- Improved performance and quality of products (goods and services);

- Decreased operational costs;

- Improved communication between people and organizations.

General standards are the result of a broad and often compromised consensus and cannot, as such, represent the exceptional excellence of a particular organization. ${ }^{2}$ This means that the creative application of the standards is a prerequisite for gaining the overwhelming advantage of them. General standards are voluntary but they may become obligatory in certain contexts through reference to standards, for instance in the contracts, regulations, and legislation. However, in these cases, too, innovations are essential for competitiveness, and not only in products but also in the organizational operations and processes.

\footnotetext{
${ }^{1}$ Juhani Anttila and Kari Jussila, "Standardization and integrated management systems - Business-practitioners' viewpoints!, 55 $5^{\text {th }}$ EOQ Congress/World Quality Congress, Navigating Global Quality in a New Era, Budapest Hungary, 2011.

${ }^{2}$ Juhani Anttila and Kari Jussila, ISO 9001:2015 - "A questionable reform. What should the implementing organisations understand and do?", Total Quality Management, 2017. http://dx.doi.org/10.1080/14783363.2017.1309119.
} 
ISO 9000 is a standards series for QM, and since 1979 its different standards have been developed through extensive international cooperation. It is also a pioneer, the best known and most widely spread one of all international management standards. The basic standards of the ISO 9000 series are the ISO 9004 for quality management (QM) in a broad sense and ISO $9001^{3}$ for quality assurance (QA). Often, however, organizations applying the ISO 9000 standards have not clearly recognized the differences and relationship of the ISO 9004 and ISO 9001 standards. Hence, the use of ISO 9004 has been negligible and misunderstood, and its benefits have not been exploited. Overly emphasized ISO $9001^{4}$ gives too narrow and one-sided solutions, which has been harmful to the creative implementation of QM and also caused distortion in the general worldwide development of the quality profession (ISO Central office 1994).

The ISO 9004 extensively deals with QM aspects from the holistic business and organization point of view. QA and ISO 9001 represent a sub-area of QM and focus on general assurance requirements to create confidence and satisfaction in the organization's products among its customers. ISO 9001 may be useful in contractual contexts, and if so needed, it can also be used as a basis for auditing and certification. ISO 9001 does not define the organizational quality management system (QMS) as a whole.

Usage of the ISO 9004 and the whole ISO 9000 standards series supports enhancing business performance through:

- Increasing key competencies within business leaders, workers, and experts;

- Diminishing uncertainties in business activities;

- Releasing resources of business leaders from acute problem eliminating to proactive business development;

- Avoiding amateurism and trial-and-error approach in business actions;

- Obtaining professional appreciation from stakeholders;

- Indicating opportunities for QM innovation.

ISO 9004 standard emphasizes that the organization's identity and its differentiating competitive advantages are the basis for the organization's sustained success. In this context, sustained success means that the organization's business continues for an extended period or without interruption for the desired time. The standard provides guidance on how this can be realized by the means of effective and efficient QM in practice. However, QM cannot be separated from business management, and hence, a particular quality management system (QMS) is harmful. Business-integrated QM, or 'Quality Integration' as used by the authors ${ }^{5}$, is understood as the implementation of the general and specific quality concepts, principles and methodology embedded within the normal business management activities. This not only requires operational quality effectiveness and efficiency but also proactive QM in the area of strategic management. Hence, factually, QM means the quality of organization management.

ISO 9004 standard is aimed at providing QM guidance for organizations to achieve sustained success also in a complex, demanding and ever-changing environment. However, the specific issues of the contemporary business environment, for instance, in the emerging challenges of the $4^{\text {th }}$ industrial revolution ${ }^{6}$, are not explicitly taken into account in the standard.

\footnotetext{
${ }^{3}$ ISO 9001 Quality management systems - requirements, ISO, Geneva Switzerland, 2015.

${ }^{4}$ Juhani Anttila and Kari Jussila, ISO 9001:2015 - "A questionable reform. What should the implementing organisations understand and do?", Total Quality Management, 2017. http://dx.doi.org/10.1080/14783363.2017.1309119.

5 Juhani Anttila and Kari Jussila, "Understanding quality - conceptualization of the fundamental concepts of quality", (Updated and improved from the conference paper presented at QMOD 2016 Conference, Rome, Italy.), Int. J. Qual. Serv. Sci., (Vol. 9, No. 3e4), 2017.

6 Juhani Anttila and Kari Jussila, "Universities and smart cities: the challenges to high quality", Total Quality Management \& Business Excellence, 2018. DOI: 10.1080/14783363.2018.1486552.
} 
This belongs to the responsibility of each organization. The following main subject areas are covered by the ISO 9004 standard:

- Terms and definitions;

- Quality of an organization and sustained success;

- Context of an organization;

- Identity of an organization;

- Leadership;

- Process management;

- Resource management;

- Analysis and evaluation of an organization's performance;

- Improvement, learning and innovation.

This article addresses various aspects of these topics and additionally opens up theoretical and practical points of view for supporting the use of the standard for the sustained success.

Each organization has always its own existing realization and implementation of QM and way to use ISO 9000 standards, which can be improved according to the organization's business development strategies and practices. In this respect, the use of ISO 9004 is very flexible. In a natural way, an organization's targets can be achieved and the performance continually improved through the principles and practices of the learning organization. ${ }^{7}$ Organizational benefits from the QM efforts should be weighed from the viewpoint of business success. All organizations and their interested parties have unique needs and business environments. Big established organizations, SMEs, and startups are very different genres of business. ${ }^{8}$ They need different QM approaches and ISO 9000 applications.

In addition to the ISO 9000 standards, organizations also use other well-known managerial reference models, for instance, performance excellence models (or quality awards criteria). All these different means may be seen as sub-elements in the ISO 9004 implementation. ISO 9004 is also aligned with the TQM (Total Quality Management) thinking and movement. However, TQM is not any longer a popular concept ${ }^{9}$, and in fact, the concept of QM in ISO 9000 standards equals the concept of TQM.

ISO 9000 standards are constantly being developed, and organizations have challenges in the new standards creation, their understanding and applying in the particular business environments. The future concepts of QM, which are currently being developed in the ISO/TC 176 standardization committee for revising the whole ISO 9000 standardization, should also be of particular interest for the organizations when implementing the ISO 9004 standard.

Also, a lot of new challenges exist for all ISO 9000 implementations. The aim of this article is to present ideas and promote discussions when searching for new opportunities for standards-based QM solutions. The authors want that this article will broaden the horizon for critical discussion on important QM issues. This article includes collated and updated material, which the authors have presented in many different conferences, training courses, articles, etc. during recent decades. The first author was involved in publishing an ISO 9004 article $^{10}$ similar to this article about twenty years ago. That article has also been publicly available on the Internet, and its nearly a thousand readers evidence a growing interest in the subject. Therefore,

\footnotetext{
7 Juhani Anttila and Kari Jussila, "Organizational learning in developing the integrated quality management, Production engineering archives", 2018. DOI: 10.30657/pea.2018.18.01.

${ }^{8}$ Juhani Anttila and Kari Jussila, ”Implementing quality management in startups", QMOD Conference, Krakow Poland, 2019.

${ }^{9}$ Su Mi Dahlgaard-Park, “The quality movement: Where are you going?”, Total Quality Management \& Business Excellence, Volume 22, Issue 5, 2011.

${ }^{10}$ Malcolm Bird and Juhani Anttila, "Using ISO 9004 to achieve excellence”, In Cianfrani, C. A., Tsiakalis, J. J. and West, J. J. (eds.), The ASQ ISO 9000:2000 handbook, ASQ Quality Press, Milwaukee, USA, 2002.
} 
it is well-founded to re-examine the subject since, after 2000, the ISO 9004 standard has been revised twice and completely rewritten recently.

In addition to the opportunities, the article also discusses some of the practical difficulties and pitfalls associated with the ISO 9004 standard, and their possible solutions. The first author of the article has a long experience in the international preparation process of the ISO 9004 standard-editions since the 1980s and both authors in the practical promotion and application of the standard in different kinds of organizations.

\section{ONTOLOGICAL AND EPISTEMOLOGICAL FOUNDATION}

The international standardization and standards are based on the consolidated results of science. ${ }^{11}$ Science describes reality through theories. The ontology and epistemology provide a solid scientific basis for organizational management and thus for QM, also. ${ }^{12}$ This helps us in understanding and conceptualizing the complex entirety of the quality phenomena and related details in today's organizational and societal environments. This approach also supports creating ideas and methodologies for dealing with the relevant problems of the QM. On the other hand, through practical applications, the theories are being tested, which in turn leads to the improvement of the theories. ${ }^{13}$

Business ontology means an extensive awareness of all aspects of the business, ${ }^{14}$ and it consists of the concepts and categories of business phenomena, including their properties and the relations between them. Quality aspects are a subdomain in the business ontology. Ontology has direct links to the organization's operational practices and organization-internal standards, where also international standards can be utilized.

ISO 9004 terms and concepts are consistently based on the terminology of the ISO 9000 standard, ${ }^{15}$ which also is aligned with the general terminology principles and practices. The most important terms and concepts that are necessary for standard-based QM implementations are:

- Quality: Degree to which an object fulfills the needs and expectations;

- Quality management (QM): Management of an organization with regard to quality (in the sense of Quality Integration);

- Quality assurance (QA): Providing confidence that the needs and expectations will be fulfilled;

- Quality improvement: Increasing the ability to fulfill the needs and expectations.

With these concepts, one can ensure dealing with professional quality management in all types of organizational cases.

ISO 9001 has a restricted scope focusing only on the organization's products and on assuring the customers' needs and expectations. However, for ensuring the organization's sustained success, the organization needs to fulfill the needs and expectations of all interested parties. For this reason, ISO 9004 emphasizes that the organization should strategically determine its relevant interested parties and their specific needs and expectations. When the organization takes this into account, it is called in ISO 9004 as the quality of an organization.

\footnotetext{
${ }^{11}$ ISO Guide 2 - Standardization and related activities - General vocabulary, Geneva Switzerland, 2004.

12 Juhani Anttila and Kari Jussila, "Understanding quality - conceptualization of the fundamental concepts of quality”, (Updated and improved from the conference paper presented at QMOD 2016 Conference, Rome, Italy.), Int. J. Qual. Serv. Sci., (Vol. 9, No. 3e4), 2017.

${ }^{13}$ Peter M. Senge, Charlottre Roberts, Richard Ross and Art Kleiner, The fifth discipline fieldbook, Nicholas Brealey Publishing Limited, London, UK, 1995.

${ }^{14}$ Mark von Rosing, Overview of the Business Ontology Research \& Analysis, 2015. https://www.researchgate.net/publication/287958619_Overview_of_the_Business_Ontology_Research_Analysis ${ }^{15}$ ISO 9000, Quality management systems - Fundamentals and vocabulary, ISO, Geneva Switzerland, 2015.
} 
Also, an important difference between ISO 9001 and ISO 9004 is that ISO 9001 only focuses on operational effectiveness, but ISO 9004 also requires ensuring efficiency.

Regarding the QM definition, it should be noted that quality cannot be directly managed but only through organizational processes and their management, i.e. through the management of the entire organization. Hence, QM has an organization-internal purpose (to ensure) for success and QA an external communicative purpose (to assure) for creating and strengthening confidence among the customers and other interested parties. The challenging way to achieve a continual quality improvement is through organizational learning. ${ }^{16}$

The general quality management principles (QMPs), as defined in the ISO 9000 standard, also have a key ontological and epistemological role in all ISO 9000 standards and in the implementation of ISO 9004, too. QMPs are a set of fundamental beliefs, norms, rules, and values that are accepted as true for QM and hence can be used as a basis for QM standardization, too. QMPs emphasize what one should take into account in all contexts of ISO 9000 standardization and application. QMP's provide a profound knowledge for understanding the standard clauses. QMPs of ISO 9000 should be utilized together with the general management principles that have been articulated by many recognized business management teachers. ${ }^{17}$ These QMPs consist of the following at the title level (ISO 2015a): ${ }^{18}$

- Customer focus;

- Leadership;

- Engagement of people;

- Process approach;

- Improvement;

- Evidence-based decision making;

- Relationship management.

The ISO 9000 Standardization Committee ISO/TC 176 is currently exploring future concepts for the coming revisions of all ISO 9000 series standards. These concepts are aimed at taking into account the emerging organizational and societal changes and associated megatrends, including the $4^{\text {th }}$ industrial revolution and the UN sustainable development goals. The futures concepts to be selected are currently in the draft phase and include the following topics:

- Customer experience;

- People aspects;

- Change management;

- Integration;

- Knowledge management;

- Emerging technologies;

- Ethics \& integrity;

- Organizational culture.

Forward-looking organizations should consider these new concepts when developing their own QM solutions.

Management is defined as coordinated activities to direct and control an organization. ${ }^{19}$ Management, as well as QM, are based on knowledge. Epistemology provides the scientific basis for understanding things and conditions, and sources of related knowledge, and

\footnotetext{
${ }^{16}$ Juhani Anttila and Kari Jussila, "Organizational learning in developing the integrated quality management," Production engineering archives, 2018. DOI: 10.30657/pea.2018.18.01.

${ }^{17}$ Juhani Anttila and Kari Jussila, "Standardization and integrated management systems - Business-practitioners' viewpoints!, $55^{\text {th }}$ EOQ Congress/World Quality Congress, Navigating Global Quality in a New Era, Budapest Hungary, 2011.

${ }^{18}$ ISO 9000, Quality management systems - Fundamentals and vocabulary, ISO, Geneva Switzerland, 2015.

${ }^{19}$ Ibid.
} 
introducing to the knowledge-related methodology. Management requires a systematic way of thinking, models for reality, and a sense of good reasoning. This leads to a more objective assessing the questions of the business environment. Epistemology is a branch of philosophy generally concerned with the nature of knowledge. It asks questions such as 'How do we know?' and 'What is meaningful knowledge?' Epistemology is a clear way to critical thinking. Many business-related issues such as the nature of logical inference, why we should accept one line of reasoning over another, and how we understand the nature of evidence and its contribution to decision making, are all epistemic concerns. ${ }^{20}$

Traditionally, knowledge is defined as a "justified true belief" ${ }^{21}$ or in other words "conscious effort to establish belief upon a firm basis of reasons". In managing an organization, knowledge can relate to all aspects of an organization's operations, and it has both operational and strategic purposes. Knowledge is either explicit or implicit (tacit) knowledge.

Fact-based operation is valued as a consistent approach to business management including QM. Data can be obtained from the existing facts by measuring the conditions and processes of an organization. The scientific basis for measurements is metrology, which is a well-established discipline, whose concepts, principles, and practices are also internationally standardized. Management-relevant information is achieved when data is analyzed and linked with the organization's business questions. The ISO 9000 standards emphasize the importance of documented information for management and QM. When information is utilized collaboratively and effectively by the organization's employees and managers to guide operations, they learn and internalize the business knowledge, and hence, often in operational situations, knowledge is tacit knowledge by nature. ${ }^{22}$

All knowledge being used to run an organization is not coherent or does not base on empirical facts. In general and philosophically, all knowledge is originated from four basic sources: ${ }^{23}$

- Perception including all senses;

- Memory or authority;

- Consciousness, intuition or introspection;

- Reason and reasoning.

Critical scientific realism and scientific methods have proved to be the best theoretical basis for rational action. ${ }^{24}$ Knowledge, justified true belief, requires a theoretical basis. Deming $^{25}$ emphasized that information is not knowledge. Knowledge originates from theory. Without theory, there is no way to use the information, which comes to us in some particular instant.

Quality improvement as part of QM cannot be realized professionally without a knowledge base, and this approach also results in new knowledge. Organization-wide quality improvement is achieved through organizational learning in a natural way. ${ }^{26}$

\footnotetext{
20 Roco J. Perla and Gareth J. Parry, The epistemology of quality improvement: It's all Greek, 2011. https://qualitysafety.bmj.com/content/20/Suppl_1/i24.;

Peter Ellerton, How do you know that what you know is true? That's epistemology, 2017.

https://theconversation.com/how-do-you-know-that-what-you-know-is-true-thats-epistemology-63884.

${ }^{21}$ Neel Burton, The Problem of Knowledge, 2018.

https://www.psychologytoday.com/intl/blog/hide-and-seek/201806/the-problem-knowledge.

${ }^{22}$ Om Kumar Harsh, "Three dimensional knowledge management and explicit knowledge reuse", Journal of Knowledge Management Practice, Vol. 10, No. 2, 2009. http://www.tlainc.com/articl187.htm.

${ }^{23}$ Oliver Kim, What are the four Ways of Knowing (WOKs)?, 2009. http://www.toktalk.net/2009/12/06/what-arethe-four-ways-of-knowing-woks/.

${ }^{24}$ Ilkka Niiniluoto, Critical Scientific Realism, Oxford University Press, Oxford UK, 1999.

${ }^{25}$ William Edwards Deming, The New Economics, MIT Press, Cambridge, MA USA, 1993.

${ }^{26}$ Juhani Anttila and Kari Jussila, "Organizational learning in developing the integrated quality management", Production engineering archives, 2018. DOI: 10.30657/pea.2018.18.01.
} 
Any organization in striving for sustained success should have necessary and sufficient knowledge of various specialized disciplines as described, for instance, in the various management system standards. These disciplines support business leaders' and employees' decisions and actions. However, situations may exist, where causality is difficult to understand and people have different beliefs and personal biases. Hence, employees and business leaders have to negotiate in order to understand the situations that they are facing. Leadership language has an important role. ${ }^{27}$ An organization is a living organism and a set of conversations among people. Language defines the environment, in which the organization lives. A common shared language helps the organization arrive at decisions more efficiently. By narrowing language, efficiency increases but also ignorance increases, which leads to the fact that the organization becomes unable to adapt and revitalize itself to challenging changes in its environment. An organization is able to learn and grow only if it creates conditions that help generate a new language, with which the organization can create new paths to productivity, and regenerate itself.

\section{THE ORGANIZATION AND ITS INTERNAL AND EXTERNAL CONTEXT}

The concept of organization is a core issue in all managerial contexts including QM and ISO 9004. An organization is a group of people, which has its own functions with responsibilities, authorities, and relationships to achieve its objectives. ${ }^{28}$ Even one single person can be a singular case of an organization. The concept includes, but is not limited to sole-trader, company, corporation, firm, enterprise, authority, partnership, charity, or institution, or part or combination thereof, whether incorporated or not, public or private. The organization may be a big one or SME (small or medium-sized enterprise). In today's business environment SMEs are seen as the backbone of the economy of countries and regions, providing potentials for jobs, renewal of organizations and economic growth. More than $99 \%$ of the organizations are SMEs. Startups also have become a significant business area. They are human institutions designed to create new products under conditions of extreme uncertainty. ${ }^{29}$ The future is pioneered by startups, not existing companies. Startups exist also within large organizations. The most management practices and also ISO 9000 standards have been developed for well-established organizations and predictable business environments. However, the situation in the SMEs and startups is very different; they are different organizational genres and hence require different management methodologies and creative application of the general standards. ${ }^{30}$

Because of the organized people and their objectives, the organization can be understood as a system, i.e. as a collection of interrelated or interacting real-world items organized for a given purpose. Many recognized management experts emphasize the system aspects in the management of the organizations. All systems always have the internal and external context. Through its border, the system interacts with its environments. The system functions through interrelated or interacting activities of processes, which transform certain inputs into desired outputs. $^{31}$

\footnotetext{
${ }^{27}$ Paul Pangaro, Notes on the role of leadership and language in regenerating organizations, 2013. available at: http://pangaro.com/leadership-language-regenerating-organizations.html.

${ }^{28}$ ISO 9000, Quality management systems - Fundamentals and vocabulary, ISO, Geneva Switzerland, 2015.

${ }^{29}$ Eric Ries, The lean startup: How today's entrepreneurs use continuous innovation to create radically successful businesses, Random House, New York USA, 2011.

${ }^{30}$ Juhani Anttila and Kari Jussila, "Implementing quality management in startups", QMOD Conference, Krakow Poland, 2019.

31 Juhani Anttila and Kari Jussila, "An advanced insight into managing business processes in practice”, Total Quality Management \& Business Excellence, Vol. 24, No. 7-8, 2013.
} 
Sustained success requires a differentiated approach that reflects the competitive identity of the organization. In this article, the organizational identity is understood as the character, profile, or personality of an organization, and it consists of five perspectives: ${ }^{32}$

a) Organization's culture and its development and linkages;

b) Organization's brand characteristics;

c) Business ideas;

d) Managing principles and architecture;

e) Interactions and transactions with the interested parties or stakeholders.

The internal context of an organization consists of values, culture, knowledge, and operational performance. ${ }^{33}$ Especially the business processes have the main role in the internal context. Also, QM and QA have the same foundation. Management of an organization consists of two main responsibilities (figure 1), which are very different managerial areas and based on different foundations:

a) Operational management of daily activities by using reactive and rational fact-based performance control and problem-solving,

b) Strategic management where the strengths, competitive advantages, and challenges of the organization are utilized in order to proactively improve the organization's business performance by recognizing, inventing, and implementing new solutions. Strategic management is very much related to change management.

Figure 1. An organization's internal context and its strategic and operational management elements, which are the foundation for QM and QA implementation

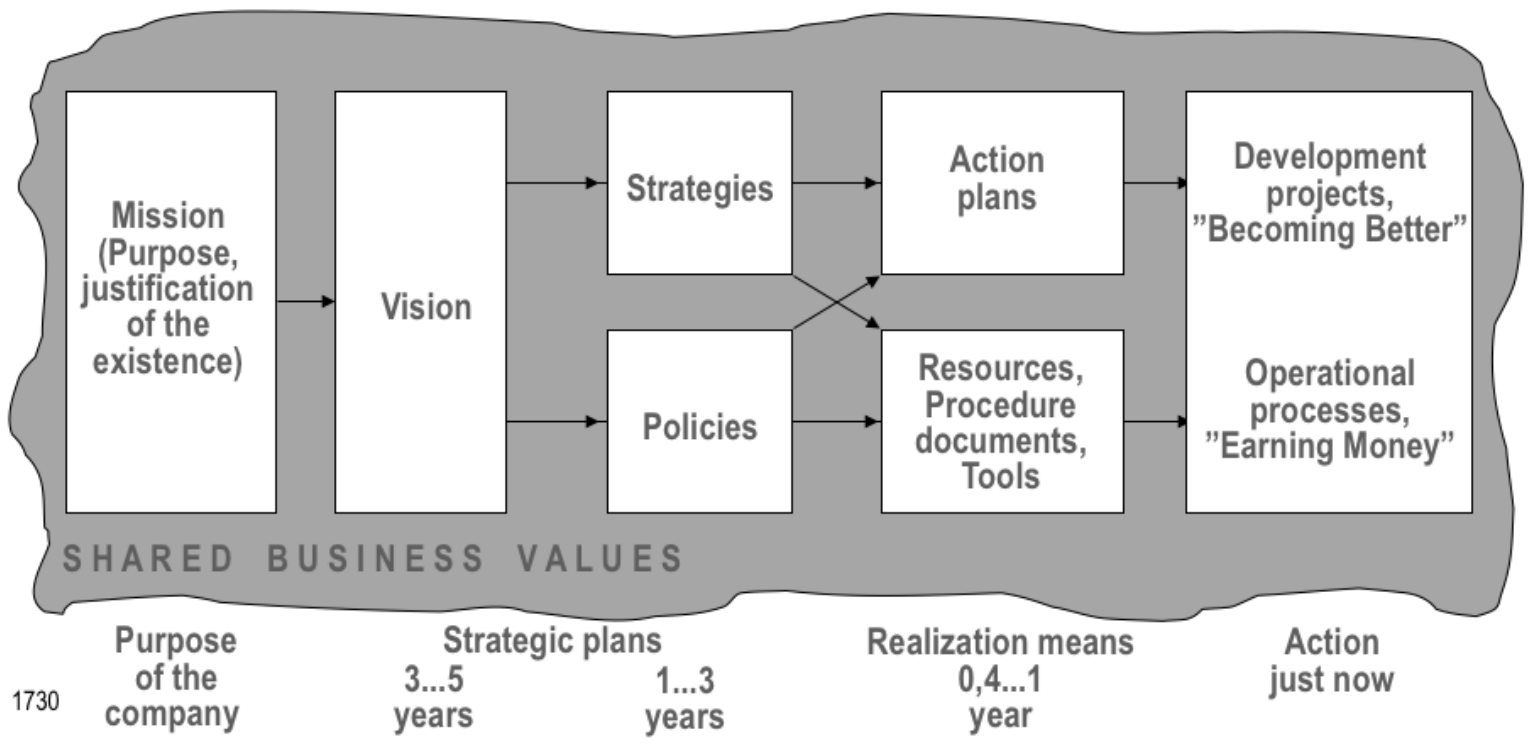

Source: Juhani Anttila and Kari Jussila, "Organizational learning in developing the integrated quality management", Production engineering archives, 2018.

The external context of an organization consists of the value network, which includes issues arising from the legal, technological, competitive, market, cultural, social and economic

\footnotetext{
32 Juhani Anttila and Kari Jussila, "The growth of an organization's identity and the management systems standardization", Proceedings of the $15^{\text {th }}$ International Symposium on Quality, Quality, growth and development, Croatian Quality Managers Society, Zagreb, Croatia, 2014, pp. 29-49.

${ }^{33}$ Ibid.
} 
environments. ${ }^{34}$ The organization's relevant interested parties are those, which strongly affect or are affected by the decisions or activities of the organization. ${ }^{35}$ Hence these parties have a crucial impact on the organization's ability to achieve sustained success. Different parties should be considered separately for QM and QA because they have different needs and expectations with regard to the organization. This relates to the product and confidence requirements. In this context, the key QM and QA related questions with regard to each relevant interested party include the following: ${ }^{36}$

- Who is the relevant interested party?

- Why is the party relevant, what is its value to the organization?

- Why is the party interested in the organization, what is its value to the party?

- What is the organization's contribution (output or product) to the party?

- How to contribute to the party (policy and processes)?

\section{ORGANIZATION-WIDE PROCESS MANAGEMENT}

Organizations are business systems that consist of interrelated business processes and organizational structures ${ }^{37}$ Performance of the business processes has the greatest strategic and operational importance to the organizations' competitiveness and sustained success. All products (goods and services) and other organizational outcomes are the results of processes. Processes imply to all kinds of activities, which are performed by people or by the hardware or software mechanisms. In fact, originally the process concept just denotes any kind of productive doing. Basic work activities that exist in all organizations can be called as 'elementary processes'. They typically include:

- Working for something;

- Moving people, material, or information;

- Interacting and communicating.

When the elementary processes within an organization are linked with achieving the organization's business results, one can talk about business processes.

The process/structure-dichotomy may lead to a dilemma: ${ }^{38}$ should the organization's management be based on processes or structures? Although processes should be prioritized, the optimum solution is a proper balance between process and structure. Adequate structures are needed for enhancing the effectiveness and efficiency of processes. Managing for balance requires trade-off decisions per each process, for instance, between freedom and control, awareness and instructions, people and systems, and proactive and reactive approaches.

According to the authors' experience in different kinds of organizations, a four-level business infrastructure model has proved useful for managing a comprehensive system of business processes. This organizational framework consists of the following four business activity/management levels that have a remarkable importance in managing the organization comprehensively: ${ }^{39}$

\footnotetext{
${ }^{34}$ ISO 9004 Quality management - Quality of an organization - Guidance to achieve sustained success, ISO, Geneva Switzerland, 2018.

${ }^{35}$ ISO 9000, Quality management systems - Fundamentals and vocabulary, ISO, Geneva Switzerland, 2015.

${ }^{36}$ Juhani Anttila and Kari Jussila, "Implementing quality management in startups", QMOD Conference, Krakow Poland, 2019.

${ }^{37}$ Juhani Anttila and Kari Jussila, "An advanced insight into managing business processes in practice", Total Quality Management \& Business Excellence, Vol. 24, No. 7-8, 2013.

${ }^{38}$ Ibid.

${ }^{39}$ Juhani Anttila and Kari Jussila, "Organizational learning in developing the integrated quality management," Production engineering archives, 2018. DOI: 10.30657/pea.2018.18.01.
} 
- Corporate level (the whole organization): Establishing and maintaining the fundamental and normative process concepts, principles, visions, and general process management methodology.

- Strategic business level: Establishing and managing the system of interlinked business processes towards strategic targets of the particular strategic business units within the corporation.

- Operational level: Managing individual business processes in real-time.

- Individual personal and team level: Emphasizing the human commitment and role in business processes.

A strategic business system may be described by four major domains of business processes:

- Market processes: Anticipating the current and future market requirements. Launching new competitive products/solutions to the market, establishing and maintaining product management, and practicing market communication.

- Customer processes: Fulfilling individual customers' needs with products, and establishing and practicing high-quality customer relationships and servicing.

- Management processes: Controlling and enhancing business performance, managing the organization's business processes as a whole.

- Support processes: Providing effective support to the business processes and management in the organization.

Process management implies how the strategic and operational business objectives are carried out through business processes. A well-known and simple model for all management, including process management, is the PDCA (Plan - Do - Check - Act) model ${ }^{40}$, which should be applied in three different management scopes (the authors call it as 'Triple' PDCA model: ${ }^{41}$

- Control: Managing daily operations in business processes in order to achieve the specified results. Normally rectifying nonconformities is carried out in connection with control.

- Operational improvements: Solving acute problems and implementing operational small-step improvements in business processes ('Kaizen').

- Breakthrough improvements: Inventing and implementing strategically significant changes successfully in the business-wide process system and transforming organizations.

The ISO 9004 standard devotes a whole chapter to the organization's resource management, how the resources support the operation of all processes in the organization and are critical for ensuring effective and efficient performance and sustained success. In particular, the following resources are highlighted: ${ }^{42}$

- Financial resources;

- People;

- Information and organizational knowledge;

- Technology;

- Infrastructure, such as equipment, facilities, energy and utilities;

- The environment for the organization's processes;

- The materials needed for the provision of products (goods and services);

- Natural resources;

\footnotetext{
40 Juhani Anttila and Kari Jussila, "Organizational learning in developing the integrated quality management," Production engineering archives, 2018. DOI: 10.30657/pea.2018.18.01.

${ }^{41}$ Ibid.

42 ISO 9004 Quality management - Quality of an organization - Guidance to achieve sustained success, ISO, Geneva Switzerland, 2018.
} 
- Resources provided externally, including subsidiaries, partnerships, alliances, and outsourced processes.

For these resources, a lot of various management systems have been presented in various sources. The most appropriate way is to implement and manage them within the organizational $\mathrm{QM}$ and process management.

People are the most significant resources in the organizations' business processes and in the roles of business leaders, managers, and employees. In order to avoid problems in the personal work-actions and in interpersonal collaboration, the business process activities and personal somaesthetic, mental, and spiritual processes should not be in conflict with each other ${ }^{43}$ Human activities have a crucial role in the realization of quality through producing products (goods and services) that effectively and efficiently fulfill the needs and expectations of customers and the other relevant interested parties. Particularly, the position and responsibilities of process owners and their relationships with the line managers are important topics in process management.

The information, digital and telecommunication technologies provide unlimited opportunities for new product development and business process solutions (Anttila and Jussila 2018b). ${ }^{44}$ This includes 5G networks, Cloud computing, Internet of things (IoT), Industrial Internet, Big data, Biohacking, Artificial intelligence (AI), Machine learning, Intellectual robotics, 3D printing, Additive manufacturing, Augmented reality, and Blockchain. Also, other technologies, including biotechnology, nano and micro-technology, optical technology, energy technology, social technology, and wellbeing technology mean big opportunities but also challenges and risks.

\section{PERFORMANCE EVALUATION}

Performance evaluation of an organization is a normal management activity incorporated with the improvement of the business system. It also is an important part of QM. Self-assessment is a fact-based business performance improvement approach deployed in accordance with business requirements and preconditions. It covers the organization's or a unit's business scope as a whole. Relevant viewpoints being addressed in the self-assessment are identified from the business requirements.

In general, two different methodological approaches are available for the selfassessment: ${ }^{45}$

a) Evaluations based on maturity models, and

b) Evaluations based on performance excellence models.

The first one is for assessing the performance against certain specified maturity level criteria based on the existing best practices. The latter emphasizes the continual performance growth based on learning, refining, and integrating. ISO 9004 standard provides in its annex a self-assessment tool, which is based on the approach (a). However, the authors' preferred approach is the option (b) because it is more proactive to respond to future challenges.

Critical views can be presented for maturity-model based assessments. Performance excellence models have achieved a more recognized position in all kinds of organizations and

\footnotetext{
43 Juhani Anttila and Kari Jussila, "An advanced insight into managing business processes in practice", Total Quality Management \& Business Excellence, Vol. 24, No. 7-8, 2013.

${ }^{44}$ Juhani Anttila and Kari Jussila, "Universities and smart cities: the challenges to high quality”, Total Quality Management \& Business Excellence, 2018, DOI: 10.1080/14783363.2018.1486552.

45 Juhani Anttila and Kari Jussila, "Understanding quality - conceptualization of the fundamental concepts of quality", 2017. (Updated and improved from the conference paper presented at QMOD 2016 Conference, Rome, Italy.), Int. J. Qual. Serv. Sci., (Vol. 9, No. 3e4), 2017b.
} 
in the general quality award. These models have been used for a long time all over the world, and they are revised regularly. The most well-known models are the American Malcolm Baldrige model and the European EFQM model. The ISO 9004 assessment methodology cannot likely compete with these practices. In the maturity models, the different evaluation areas are assessed separately, and the model does not provide clear links between them. Results are not evaluated at all in the maturity models. Hence in practice, it is difficult to get holistic business performance from the evaluation-item related results. Because the criteria are general and standardized, the relevance to the specific organizational situations and needs is not necessarily ensured. Best practices of the maturity models do not necessarily present brand new creative organization-specific solutions. Maturity is not necessarily a good business target for success, which depends on the nature of the organization and its activities. Many organizations prefer agility more than maturity. For instance, SMEs and startups, do not want to strive for maturity, because it does not represent their sustained success that is more based on dynamics and continual regeneration.

In performance excellence models, the evaluation criteria take into account performance enablers (processes) and also the results obtained with them, and they emphasize organizational learning and integration. In order to achieve excellent performance and sustained success, the organization cannot optimize a single area of activities and neglect the entirety, but one should recognize connections between the performance of the processes (enablers) and the overall business results. Processes and results are assessed separately but the criteria emphasize the causal relations between them. Numerical scoring is based on the open assessment criteria $(\text { table } 1)^{46}$.

Table 1. An example of the scoring dimensions for the self-assessment according to the performance excellence model.

\begin{tabular}{|c|c|}
\hline Processes & Results \\
\hline $\begin{array}{l}\text { 1. Approach: The planned actions, including process } \\
\text { plans, measures, and deployment of requirements } \\
\text { 2. Deployment: Executing the planned approach in } \\
\text { practice } \\
\text { 3. Learning: Capturing new knowledge, including } \\
\text { new innovations } \\
\text { 4. Integration: Embedding the approach in the } \\
\text { organization's strategies and the management of } \\
\text { the processes and activities. }\end{array}$ & $\begin{array}{l}\text { 1. Level: Levels of the achieved results } \\
\text { 2. Trends: Sustained rate of improvement of the } \\
\text { performance results over time } \\
\text { 3. Comparisons: Performance relative to } \\
\text { appropriate comparisons or benchmarks } \\
\text { 4. Integration: Achieving the results in a } \\
\text { balanced and comprehensive manner } \\
\text { according to the organization's strategic } \\
\text { objectives and anticipating future } \\
\text { development. }\end{array}$ \\
\hline
\end{tabular}

Source: Juhani Anttila and Kari Jussila, "The role of internal auditing in the development of the organization towards the excellent performance", Proceedings of the $19^{\text {th }}$ International Symposium on Quality, Quality as a concept of development, Croatian Quality Managers Society, Plitvička jezera Croatia, 2018, pp. 335-357.

Processes and results are assessed separately and scored from 0 to $100 \%$ according to the scoring criteria. ${ }^{47}$

\footnotetext{
46 Juhani Anttila and Kari Jussila, "Organizational learning in developing the integrated quality management, Production engineering archives", 2018. DOI: 10.30657/pea.2018.18.01.

${ }^{47}$ Ibid.
} 
Self-assessments and audits complement each other. Auditing has a long development history. ${ }^{48}$ Today internal audits are well-established management tools for examining, monitoring and analyzing the organizational activities for sustained success. Internal audit helps the organization ensure that its process management operates effectively and efficiently as a whole. The first international standard for auditing quality management systems was developed along with the ISO 9000 quality management standardization, and its latest version, ISO $19011^{49}$, has expanded to cover the needs of all different management system standards. The guidelines of this standard can be used for both internal and external auditing. From the organizations' viewpoint, it is beneficial to understand all audits as the management support functions for performance improvement and QA. Hence, the audits should be carried out in a business-integrated way.

\section{BUSINESS PERFORMANCE IMPROVEMENT, RISK AND INNOVATION MANAGEMENT}

ISO 9004 standard emphasizes that the organization should continually recognize challenges in its external and internal circumstances for effectiveness and efficiency and changes in the needs and expectations of its interested parties. In this context, also organizational learning and innovation support the organization's QM and quality improvement by increasing the ability to respond to the situation in a manner that enables it to fulfill its business targets for sustained success.

In quality improvement, the organization should especially focus on improving process performance by using two basic approaches:

a) Strategic breakthrough projects, which lead to the revision of existing processes or the implementation of new processes, and which are usually carried out by the crossfunctional groups separately from the routine process-operations and

b) Continual small-step improvements made by natural work-teams within the existing process operations.

Well-established and popular systematic methodologies are available for the business process improvement based on problem-solving techniques:

- Kaizen is a Japanese term meaning "change for the better" or "continuous improvement". It is a Japanese business philosophy and practice of continuously improving operations and involving all employees. Kaizen means improvement as a gradual and methodical process. It involves making the work environment more effective and efficient by creating a team atmosphere, improving everyday procedures, ensuring employee satisfaction, and making a job more fulfilling, less tiring, and safer. There are many variations in the practical Kaizen realizations.

- SixSigma is a process focused methodology designed to improve business performance by improving specific areas of the strategic business processes. It is typically used in large scale and financially significant improvement projects in organizations that have a strong SixSigma culture. Hence, SixSigma can also be understood in a broader sense as a management-led philosophy, methodology, and tool kit for business transformation, strategic improvement, and problem-solving.

Lean methodology is also often associated with performance improvement. It aims at eliminating useless process activities and waste. It consists of a large and quite vague collection

\footnotetext{
${ }^{48}$ Juhani Anttila and Kari Jussila, "The role of internal auditing in the development of the organization towards the excellent performance", Proceedings of the $19^{\text {th }}$ International Symposium on Quality, Quality as a concept of development, Croatian Quality Managers Society, Plitvička jezera Croatia, 2018, pp. 335-357.

${ }^{49}$ ISO 19011 Guidelines for auditing management systems, ISO, Geneva Switzerland, $2018 \mathrm{~b}$.
} 
of improvement tools. Also, benchmarking methodology is used in the context of process performance improvement.

In big organizations, particular startups may be created for new strategic initiatives and for regenerating certain business areas. ${ }^{50}$

Sustained success as a major business target requires that the organization should recognize positive and negative uncertainties and their effects on objectives, which means utilizing adequate risk management practices. ${ }^{51}$ In this context, also business continuity ${ }^{52}$ and resilience ${ }^{53}$ methodologies may be useful.

Quality and innovation can be seen as partnering disciplines. ${ }^{54}$ They can be useful to each other and together create business improvements and differentiation for competitive advantage. The European technical specification CEN/TS 16555-1 defines innovation as the "implementation of a new or significantly improved product (good or service), or process, a new marketing method, or a new organizational method in business practices, workplace organization or external relations". ${ }^{5}$ In this definition, the "significantly" and "implementation" are keywords. Hence, the innovations should be conceptually new and commercially viable solutions that are available to the markets and society. Thus, in fact, all innovations aim at quality improvement. Business innovations are directly related to improving product performance, increasing the effectiveness and efficiency of the business processes, and making possible organizations' radical structural and operational reforms. All these topics are basic intentions of the professional QM.

The exploitation of new technologies is central to innovation. Technology innovations may be directed according to the two major ways by using: ${ }^{56}$

a) Sustaining technology for fostering and enhancing the existing technical features.

b) Disruptive technology for simplifying the existing technical solutions and providing a very different value proposition.

The authors have recognized serious needs for innovations also in quality practices and methodologies. ${ }^{57}$ The "from-invention-to-innovation" process is very complicated in practice and involves many different actors. ${ }^{58}$ Professional quality practices may be beneficial in this process.

Successful development of the business integration is a holistic learning process that leads on to continual refining the discipline related concepts and principles, tools and methodologies, and management practices in a compatible and balanced way. ${ }^{59}$ This organizational learning constitutes the development not just of new capacities, but of fundamental shifts of mind, individually and collectively. That is based on sensibility to new

\footnotetext{
50 Juhani Anttila and Kari Jussila, ”Implementing quality management in startups", QMOD Conference, Krakow Poland, 2019.

${ }^{51}$ ISO 31000 Risk management - principles and guidelines. Geneva Switzerland, 2018.

${ }^{52}$ First London, Business continuity, London, UK, 2003. www.thebci.org/London\%20Firsts.pdf.

${ }^{53}$ Erica Seville, What makes a resilient organization?, 2016. https://www.koganpage.com/article/what-makes-aresilient-organization.

54 Juhani Anttila and Kari Jussila, "Quality and innovation - Partnering disciplines", Proceeding of $17^{\text {th }}$ International Symposium on Quality Quality makes a difference, Croatian Quality Managers Society, Zadar, Croatia, 2016, pp. 13-35.

${ }^{55}$ CEN/TS 16555-1 Innovation management - Part 1: Innovation management system, CEN Brussels, Belgium, 2013.

${ }^{56}$ Clayton M. Christensen, The innovator's dilemma, Harvard Business School Press, USA, 1997.

57 Juhani Anttila and Kari Jussila, "Quality and innovation - Partnering disciplines", Proceeding of $17^{\text {th }}$ International Symposium on Quality Quality makes a difference, Croatian Quality Managers Society, Zadar, Croatia, 2016, pp. 13-35.

${ }^{58}$ Ibid.

59 Juhani Anttila and Kari Jussila, "Organizational learning in developing the integrated quality management”, Production engineering archives, 2018. DOI: 10.30657/pea.2018.18.01.
} 
opportunities, changing attitudes, and getting new skills. In this context, the five basic learning factors: ${ }^{60}$

- Personal mastery;

- Mental models;

- Shared vision;

- Team learning;

- Systems thinking;

are the key means by which this learning and business integration are ensured.

\section{CONCLUSION}

Professional QM is a promising approach in striving for organizations' business benefits. ISO 9004 is the most challenging general international QM standard. Its holistic organizationwide approach provides guidance for the sustained success of the organization. As a side effect, it also can lead to fulfilling the general ISO 9001 requirements of QA.

ISO 9004 is built on a systemic process-based approach and aligned with the sound scientific ontological and epistemological thinking. It makes multidisciplinary QM solutions possible in a flexible way, which easily allow the integration of different specialized managerial requirements that are presented for instance in many various management system standards. Key aspects of ISO 9004 implementation can be summarized as follows:

- Integration: Implementing effective and efficient and business-relevant quality principles and methodology embedded within the organization's normal activities of strategic and operational management. Changing emphasis from separate QM systems to the quality of organization and the quality of management.

- Responsiveness: Striving for quickly adjusting to suddenly altering business conditions and resuming stable operation without undue delay, and aiming at successful business continuity and resilience.

- Learning: Continual individual and organizational learning for quality improvement.

- Innovation: Striving continuously for new organization-dedicated creative solutions and encouraging various choices for QM in different organizations. Emphasizing the organization's unique approach instead of a forced standard approach.

- Collaboration: Communicating and working together with colleagues and appropriate multidisciplinary knowledge communities appreciating connectivity, interactivity, and shared knowledge and resources.

\section{Sažetak:}

\section{ISO 9004 - STIMULATIVNA NORMA UPRAVLJANJA KVALITETOM ZA KREATIVNE LIDERE SAVREMENIH ORGANIZACIJA}

Organizacija može imati značajne koristi od općih međunarodnih normi za sustave upravljanja ako razumije njihovu prirodu i primijeni ih kreativno i integrirano s poslovnim upravljanjem. $U$ ovom slučaju, lideri u organizacijama imaju ključnu ulogu. Ovaj članak razmatra ovu problematiku u svim vrstama organizacija s težištem na normu upravljanja kvalitetom ISO 9004, jednu od mnogih međunarodnih normi za sustave upravljanja. Norma ISO 9004 najzahtjevnija je u seriji ISO 9000 upravljanja kvalitetom. Međutim, organizacije koje primjenjuju norme ISO 9000 često jasno ne

\footnotetext{
${ }^{60}$ Peter M. Senge, Charlotte Roberts, Richard Ross and Art Kleiner, The fifth discipline fieldbook, Nicholas Brealey Publishing Limited, London, UK, 1995.
} 
prepoznaju razlike i odnos normi ISO 9004 i ISO 9001 i stoga nisu mogle iskoristiti potencijal norme u svojim implementacijama. Norma ISO 9004 naglašava da su identitet organizacije i njene različite konkurentske prednosti osnova za kontinuirani uspjeh organizacije. Svaka organizacija ima svoju i uvijek postojeću ISO 9000 realizaciju koja se može kontinuirano poboljšavati u skladu s poslovnim strategijama i poslovnim razvojem. U tom je pogledu norma ISO 9004 vrlo fleksibilna i izazovna. Pored ISO 9000 normi, organizacije koriste i druge poznate upravljačke referentne modele, uključujući, npr. modele izvrsnosti performansi i mnoge druge norme sustava upravljanja za određene discipline. Sve ovo može se promatrati kao poddomene unutar implementacije zahtjeva norme ISO 9004.Uz prilike, u članku se također raspravlja o nekim praktičnim poteškoćama i zamkama povezanim s normom ISO 9004 te mogućim rješenjima. Od 1980-ih prvi autor ovog članka prikupljao je iskustvo u međunarodnom postupku pripreme izdanja ISO 9004 i oba autora sudjelovala su u praktičnoj promociji i primjeni standarda u različitim vrstama organizacija.

Ključne riječi: kvaliteta, upravljanje kvalitetom, ISO 9004, održivi uspjeh, kvaliteta organizacije.

\section{LITERATURE}

1. Anttila J. and K. Jussila, "From quality management principles to good management principles - Business-integrated approach to quality management", The $8^{\text {th }}$ China Shanghai international symposium on quality and the forum of International Academy for Quality, Shanghai China, 2011.

2. Anttila, J. and K. Jussila, "Standardization and integrated management systems - Businesspractitioners' viewpoints, $55^{\text {th }}$ EOQ Congress/World Quality Congress Navigating Global Quality in a New Era, Budapest, Hungary, 2011.

3. Anttila, J. and K. Jussila, "An advanced insight into managing business processes in practice”, Total Quality Management \& Business Excellence, Vol. 24, No. 7-8, 2013.

4. Anttila, J. and K. Jussila, "The growth of an organization's identity and the management systems standardization", Proceedings of the $15^{\text {th }}$ International Symposium on Quality Quality growth and development, Zagreb, Croatia, 2014.

5. Anttila, J. and K. Jussila, "Quality and innovation - Partnering disciplines", Proceeding of $17^{\text {th }}$ International Symposium on Quality Quality makes a difference, Croatian Quality Managers Society, Zadar, Croatia, 2016.

6. Anttila, J. and K. Jussila, ISO 9001:2015 - A questionable reform. What should the implementing organizations understand and do? Total Quality Management, 2017.

7. Anttila, J. and K. Jussila, "Understanding quality - conceptualization of the fundamental concepts of quality", 2017. (Updated and improved from the conference paper presented at QMOD 2016 Conference, Rome, Italy.), Int. J. Qual. Serv. Sci., (Vol. 9, No. 3e4).

8. Anttila, J. and K. Jussila, "The role of internal auditing in the development of the organization towards the excellent performance", Proceedings of the $19^{\text {th }}$ International Symposium on Quality Quality as a concept of development, Croatian Quality Managers Society, Plitvička jezera, Croatia, 2018.

9. Anttila, J. and K. Jussila, "Universities and smart cities: the challenges to high quality", Total Quality Management \& Business Excellence, 2018.

10. Anttila, J. and K. Jussila, "Organizational learning in developing the integrated quality management", Production engineering archives, 2018.

11. Anttila, J. and K. Jussila, "Implementing quality management in startups", QMOD Conference, Krakow Poland, 2019.

12. Bird, M. and J. Anttila, "Using ISO 9004 to achieve excellence", 2002: In Cianfrani, C.A., Tsiakalis, J. J. and West, J. J. (eds.), The ASQ ISO 9000:2000 handbook, ASQ Quality Press, Milwaukee, USA. 
13. Burton, N., The Problem of Knowledge, (2018).

https://www.psychologytoday.com/intl/blog/hide-and-seek/201806/the-problemknowledge

14. CEN. CEN/TS 16555-1 Innovation management - Part 1: Innovation management system. CEN Brussels, Belgium, 2013

15. Christensen, C., The innovator's dilemma, Harvard Business School Press, USA, 1997.

16. Dahlgaard-Park, S. M. The quality movement: Where are you going? Total Quality Management \& Business Excellence, Volume 22, Issue 5, 2011.

17. Deming, W. E., The New Economics, MIT Press, Cambridge, MA USA, 1993.

18. Ellerton, P., "How do you know that what you know is true? That's epistemology", 2017. https://theconversation.com/how-do-you-know-that-what-you-know-is-true-thatsepistemology-63884

19. Harsh, O. K. "Three dimensional knowledge management and explicit knowledge reuse", Journal of Knowledge Management Practice, Vol. 10, No. 2, 2009. http://www.tlainc.com/articl187.htm

20. ISO/IEC Annex L (normative) Proposals for management system standards, ISO/IEC Directives, Part 1 Consolidated ISO Supplement - Procedures specific to ISO, ISO, Geneva Switzerland, 2019.

21. ISO/IEC Guide 2 Standardization and related activities - general vocabulary, ISO, Geneva Switzerland, 2004.

22. ISO Central Office. (1994, July 14). Press release. ISO, Geneva Switzerland, 1994.

23. ISO 9004 Quality management - Quality of an organization - Guidance to achieve sustained success, ISO, Geneva Switzerland, 2018.

24. ISO 19011 Guidelines for auditing management systems, ISO, Geneva Switzerland, 2018.

25. ISO 31000 Risk management - principles and guidelines, Geneva Switzerland, 2018.

26. ISO 9000, Quality management systems - Fundamentals and vocabulary, ISO, Geneva Switzerland, 2015.

27. ISO 9001 Quality management systems - requirements, ISO, Geneva Switzerland, 2015.

28. ISO Guide 2 - Standardization and related activities - General vocabulary, Geneva Switzerland, 2004.

29. Kim, O. (2009). What are the four Ways of Knowing (WOKs)? http://www.toktalk.net/2009/12/06/what-are-the-four-ways-of-knowing-woks/

30. London, F. Business continuity. London, UK, 2003. www.thebci.org/London\%20Firsts.pdf.

31. Niiniluoto, I., Critical Scientific Realism, Oxford University Press, Oxford UK, 1999.

32. Pangaro, P., Notes on the role of leadership and language in regenerating organizations, 2013.

available at: http://pangaro.com/leadership-language-regenerating-organizations.html.

33. Perla, R. and G. Parry, The epistemology of quality improvement: It's all Greek https://qualitysafety, 2011. bmj.com/content/20/Suppl_1/i24.

34. Ries, E., The lean startup: How today's entrepreneurs use continuous innovation to create radically successful businesses, Random House, New York USA, 2011.

35. Senge, P., Roberts, Charlotte, Ross, B. and A. Kleiner, "The fifth discipline fieldbook", Nicholas Brealey Publishing Limited, London, UK, 1995.

36. Seville, Erica, What makes a resilient organization? 2016. https://www.koganpage.com/article/what-makes-a-resilient-organization.

37. von Rosing, M. Overview of the Business Ontology Research \& Analysis, 2015. https://www.researchgate.net/publication/287958619_Overview_of_the_Business_Ontolo gy_Research_Analysis 